\title{
Quality Assessment of Groundwater from the Coal Bearing Aquifer in the Xinji Coalfield, Anhui Province, China
}

\author{
S.B. Feng* and L.H. Sun** \\ *School of Resources and Civil Engineering, Suzhou University, Anhui 234000, China \\ **Key Laboratory of Mine Water Resource Utilization of Anhui Higher Education Institute, Suzhou University, \\ Anhui 234000, China \\ $†$ Corresponding author: L.H. Sun; sunlinh@126.com
}

Nat. Env. \& Poll. Tech Website: www.neptjournal.com

Received: 21-10-2019

Revised: $19-11-2019$

Accepted: 11-12-2019

Key Words:

Quality assessment

Groundwater quality

Coal bearing aquifer

Xinji coalfield

\begin{abstract}
In this study, a total of 50 groundwater samples from the coal-bearing aquifer in the Xinji coalfield (one sub-coalfield of the Huainan coalfield) have been collected, and their major ion concentrations have been measured for the evaluation of its suitability for drinking and irrigation, and then the mechanism controlling the water chemistry have been analysed. The results indicate that the groundwater samples are slightly alkaline with TDS higher than the freshwater ( $<1000 \mathrm{mg} / \mathrm{L}$ ), and most of them are classified to be $\mathrm{Cl}^{-}$and $\mathrm{HCO}_{3}{ }^{-}$types. The groundwater samples have WQI range from 5.63 to 179 (mean = 64.9), suggesting that these samples are good for drinking. However, the results of sodium adsorption ratio and residual sodium carbonate indicate that only a few of the samples can meet the requirement of irrigation, but must be treated before application. Gibbs diagram and the relationships between major ions, as well as the factor analysis, imply that water-rock interaction is the main process controlling the groundwater chemistry, including the dissolution of evaporate minerals and the weathering of silicate minerals.
\end{abstract}

\section{INTRODUCTION}

Water is the most important resource in the world, not only because it is essential for life, but also its role played in human activities including the agriculture and industry. Among all of the water resources, the groundwater makes up about $20 \%$ of the world's freshwater supply (Lvovitch 1970), and the global groundwater storage is equal to the total amount of freshwater stored in the snow and ice pack of the earth.

To be one of the most important agricultural bases of China, the North China Plain has played a fundamental role during the evolutionary history of China. However, because of the lacking of the surface water resource, the groundwater has played an important role in the development of the area (Chen et al. 2005). Near 56\% of the water supply for more than 100 million people is provided by groundwater and most of the area use groundwater for irrigation. In some of the cities (Beijing, Shijiazhuang, Handan), the groundwater accounts for more than $70 \%$ of the water supply in recent years (Zhang et al. 2000).

Meanwhile, the North China Plain is an important energy base of China, because of its high reserves of coal and petroleum. There are many large coalfields (e.g. Lianghuai coalfield) and oilfields (e.g. Dagang, Shengli, Huabei \&
Zhongyuan) distributed in the plain. Similar to other areas, these oil and coal fields are also lacking water. However, paradoxically, during the production of coal, a large quantity of water from the underground need to be discharged for the safety of coal mining, because water is considered to be the most dangerous one among the five typical disasters in coal mines (including water, fire, gas, dust, roof), as water inrush has brought to human with the highest loss (Gui \& Chen 2007). And therefore, how to control the water hazard with the utilization of the water resource simultaneously has become an important issue concerned by the governments and the scientists.

There are two main coalfields in the northern Anhui province, China, which are located north and south to the Huai River, namely the Wanbei coalfield and the Huainan coalfield. During the last ten years, the groundwater in the Wanbei coalfield has been systematically studied (Sun \& Gui 2013, Lin 2016, Sun 2018), whereas the groundwater in the Huainan coalfield, especially the quality aspect has not been well considered yet. Therefore, in this study, a total of 50 groundwater samples from the coal-bearing aquifers in four coal mines in the Xinji coalfield (one sub-coalfield of the Huainan coalfield) have been collected, and their major ion concentrations have been measured for the evaluation of its 
quality for drinking and irrigation, and then the mechanism controlling the water chemistry has been studied. The reason for choosing this aquifer is because it is a direct threat to the safety of coal mining and the main source of water discharged during coal mining.

\section{MATERIALS AND METHODS}

\section{Hydro-Geological Background}

Xinji coalfield is located in the middle-north of the Anhui province, China. There are five coal mines in the area: the Banji coalmine, Xinji coalmine, Yangcun coalmine, Kouzi coalmine and Liuzhuang coalmine, which are located west to the Fengtai County and north to the Yinshang County, with a total area of $425 \mathrm{~km}^{2}$ (Fig. 1). The designed production of coal in the field is more than 30 million tons per year. Water resources in the area are rich because the Huai River and its tributaries flow through the area. The climate of the area is mild and belongs to marine-continental climate with an annual average temperature of $15.1^{\circ} \mathrm{C}$. The average annual rainfall is $884 \mathrm{~mm}$, and most of them concentrated in June to August. However, the groundwater is the main water source for the industry and domestic use in the coal mine areas, because they are located far away from the rivers.

Previous investigations revealed that there are five main aquifer systems in the coalfield from shallow to deep; the loose layer aquifer system, the Permian coal-bearing sandstone aquifer system, the Carboniferous limestone aquifer system, the Ordovician limestone aquifer system and the Cambrian nappe aquifer system. Among these five aquifer systems, the groundwater in the Permian coal-bearing sandstone aquifer system is the direct threat for the safety of coal mining, similar to the Huaibei coalfields (Sun 2018).

\section{Methods}

A total of 50 groundwater samples were collected from the coal-bearing aquifers in the four coal mines of the coalfield: 10, 10, 15 and 15 from the Banji, Kouzi, Liuzhuang and Xinji coalmines (Table 1). Water $\mathrm{pH}$ and total dissolved solids (TDS) were measured in the field with a portable $\mathrm{pH}$-meter

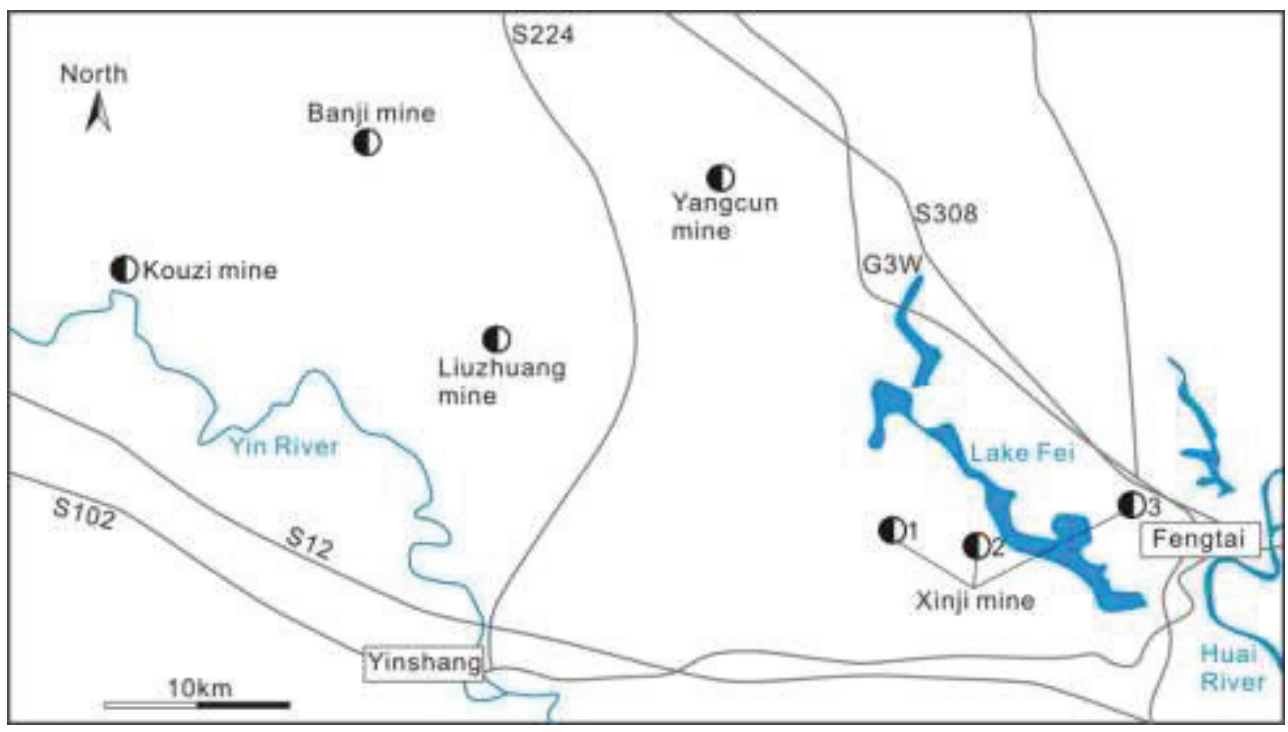

Fig. 1: Locations of the coal mines related to this study.

Table 1: Mean major ion concentrations $(\mathrm{mg} / \mathrm{L})$ of the groundwater samples.

\begin{tabular}{|lllllllllll|}
\hline Location & Number & $\mathrm{pH}$ & $\mathrm{Na}^{+}$ & $\mathrm{Ca}^{2+}$ & $\mathrm{Mg}^{2+}$ & $\mathrm{Cl}^{-}$ & $\mathrm{SO}_{4}{ }^{2-}$ & $\mathrm{HCO}_{3}^{-}$ & $\mathrm{CO}_{3}{ }^{2-}$ & $\mathrm{TDS}^{-}$ \\
\hline Banji & 10 & 8.23 & 465 & 20 & 10 & 485 & 48 & 392 & 25 & 1249 \\
Kouzi & 10 & 8.19 & 932 & 10 & 6 & 409 & 162 & 1137 & 159 \\
Liuzhuang & 15 & 8.06 & 788 & 18 & 14 & 658 & 135 & 691 & 55 & 2246 \\
Xinji & 15 & 8.34 & 627 & 31 & 23 & 636 & 77 & 460 & 63 \\
\hline
\end{tabular}


and TDS-meter. Water samples were filtered through 0.45 $\mu \mathrm{m}$ pore size membranes and collected into 2-L polyethylene bottles that had been cleaned in the laboratory. Then, the samples were sent to the laboratory for analyses of major ions. $\mathrm{Na}^{+}, \mathrm{Ca}^{2+}, \mathrm{Mg}^{2+}, \mathrm{Cl}^{-}$and $\mathrm{SO}_{4}{ }^{2-}$ were measured by ion chromatography, whereas alkaline (including $\mathrm{HCO}_{3}{ }^{-}$and $\mathrm{CO}_{3}{ }^{2-}$ ) was analysed by acid-base titration. The quality control was carried out by standard sample (the correlation coefficient between actual concentration and measured concentration was higher than 0.99). All the analysis was conducted in the Engineering Research Centre of Coal Mine Exploration, Anhui province, China.

\section{RESULTS AND DISCUSSION}

\section{Major Ion Concentrations}

The analytical results of the major ion concentrations are given in Table 1 . As can be seen from the table, all the groundwater samples have $\mathrm{Na}^{+}$concentration much higher than $\mathrm{Ca}^{2+}$ and $\mathrm{Mg}^{2+}$ for the cations, whereas $\mathrm{Cl}^{-}$and $\mathrm{HCO}_{3}{ }^{-}$are the dominant anions. However, although all the groundwater samples were collected from similar aquifers in four coal mines, their major ion concentrations are different from each other. Detailed information about the major ion concentrations is as follows.

The mean concentrations of $\mathrm{Na}^{+}, \mathrm{Ca}^{2+}, \mathrm{Mg}^{2+}, \mathrm{Cl}^{-}, \mathrm{SO}_{4}{ }^{2-}$, $\mathrm{HCO}_{3}{ }^{-}$and $\mathrm{CO}_{3}{ }^{2-}$ for the groundwater samples from the Banji coalmine are 465, 20, 10, 485, 48, 392 and $25 \mathrm{mg} / \mathrm{L}$, respectively. The decreasing order of mean concentrations of major ions is $\mathrm{Cl}^{-}>\mathrm{Na}^{+}>\mathrm{HCO}_{3}{ }^{-}>\mathrm{SO}_{4}{ }^{2-}>\mathrm{CO}_{3}{ }^{2-}>\mathrm{Ca}^{2+}>\mathrm{Mg}^{2+}$. This order is consistent with those of the groundwater from the Xinji coalmine (Table 1), the mean concentrations of $\mathrm{Na}^{+}$, $\mathrm{Ca}^{2+}, \mathrm{Mg}^{2+}, \mathrm{Cl}^{-}, \mathrm{SO}_{4}{ }^{2-}, \mathrm{HCO}_{3}{ }^{-}$and $\mathrm{CO}_{3}{ }^{2-}$ for the groundwater samples from it are 627, 31, 23, 636, 77, 460 and $63 \mathrm{mg} / \mathrm{L}$, respectively. Comparatively, the groundwater samples from the Kouzi and Liuzhuang coalmines have higher mean $\mathrm{Na}^{+}$ and $\mathrm{HCO}_{3}{ }^{-}$but lower mean $\mathrm{Ca}^{2+}$ and $\mathrm{Mg}^{2+}$ concenrtations relative to the Banji and Xinji coalmines, and the concentration orders are also different. Such a phenomenon suggests that the hydrological conditions of all the coalmines are overall consistent with each other, but there are still some differences (e.g. the water-rock interactions).

The mean total dissolved solids (TDS) of the groundwater samples from the four coalmines varied from 1249 to 2246 $\mathrm{mg} / \mathrm{L}$, and all the samples have TDS higher than the freshwater $(<1000 \mathrm{mg} / \mathrm{L})$ (Davis \& Dewiest 1966). The mean $\mathrm{pH}$ values of the samples range from 8.06 to 8.34, implying that the groundwater samples are slightly alkaline.

\section{Hydrochemical Types}

Classification of hydrochemical types for groundwater is important because of the dominant anion species of water change systematically from $\mathrm{HCO}_{3}{ }^{-}, \mathrm{SO}_{4}{ }^{2-}$ to $\mathrm{Cl}^{-}$as groundwater flows from the recharge zone to the discharge zone (Toth 1999, Jalali 2005). And therefore, the classification of the hydrochemical types in this study can provide information for the understanding of the hydrological evolution of the studied aquifers. Classification of water in this study is based on the concentrations of cations and anions by using the software Aquachem and Piper diagram, and the result is shown in Fig. 2.

The result indicates that all the groundwater samples from the four coalmines are mainly classified to be of two

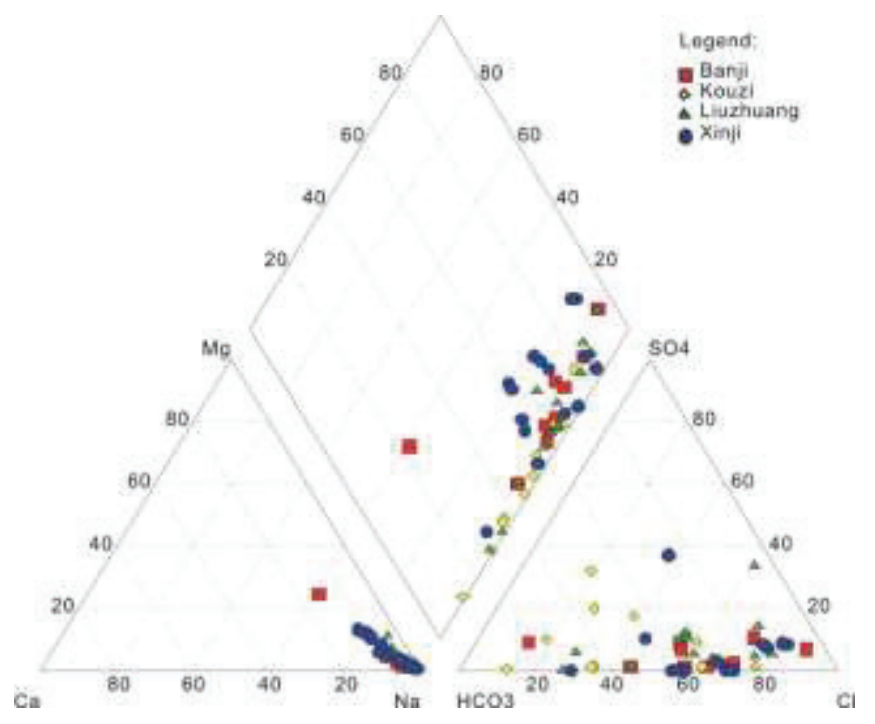

Fig. 2: Piper diagram. 
types $\left(\mathrm{Cl}^{-}\right.$and $\mathrm{HCO}_{3}{ }^{-}$types). For the groundwater samples from the Banji, Liuzhuang and Xinji coalmines, most of the samples are classified to be $\mathrm{Na}-\mathrm{Cl}$ type ( $80 \%$ of the samples, respectively), whereas the groundwater samples from the Kouzi coalmine are mainly classified to be the $\mathrm{Na}-\mathrm{HCO}_{3}$ type $(70 \%)$. Such results suggest that the hydrological condition of these four coalmines are different from each other. The groundwater from the former three coalmines might have been affected by more serious of the evaporation (e.g. located in the discharge zone) or dissolution of the evaporate minerals (e.g. halite or gypsum), whereas the groundwater from the Kouzi coalmine might have been influenced by the weathering of silicate minerals (Sun 2018).

\section{Quality Evaluation for Drinking}

There are several methods been applied for the water quality evaluation, and the most popular applied ones include the comparison with the quality standard (e.g. World Health Organization) (WHO 2008) and the water quality index (WQI) (Varol \& Davraz 2015). The latter was calculated for evaluating the quality for drinking based on several key parameters of water chemistry according to their different importances in the overall quality of water for drinking purposes (Vasanthavigar et al. 2010). The assigned weight ranges from 1 to 5 . The maximum weight of 5 has been assigned for TDS, $\mathrm{Cl}^{-}$and $\mathrm{SO}_{4}{ }^{2-}, 4$ for $\mathrm{Na}^{+}$, and 3 for $\mathrm{Ca}^{2+}$ and $\mathrm{Mg}^{2+}$. The detailed process is as follows:

First step: weight calculation with equation $\mathrm{Wi}=\mathrm{wi} / \sum_{i=1}^{n} w i$, where $\mathrm{Wi}$ is the relative weight, wi is the weight of each parameter, $n$ is the number of parameters.

Second step: quality rating with equation $\mathrm{Qi}=100 \times \mathrm{Ci} /$ $\mathrm{Si}$, where $\mathrm{Qi}$ is the quality rating, $\mathrm{Ci}$ is the concentration of each chemical parameter $(\mathrm{mg} / \mathrm{L})$, and $\mathrm{Si}$ is the World Health Organization standard $\left(\mathrm{Na}^{+} 200 \mathrm{mg} / \mathrm{L}, \mathrm{Ca}^{2+} 300 \mathrm{mg} / \mathrm{L}_{,} \mathrm{Mg}^{2+}\right.$

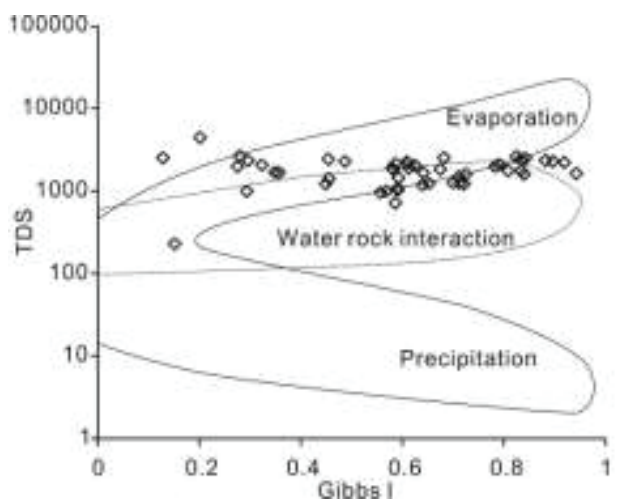

$30 \mathrm{mg} / \mathrm{L}, \mathrm{Cl}^{-} 250 \mathrm{mg} / \mathrm{L}, \mathrm{SO}_{4}{ }^{2-} 250 \mathrm{mg} / \mathrm{L}$, TDS $1500 \mathrm{mg} / \mathrm{L}$ ) (WHO 2008).

Third step: water quality index calculation with equation $\mathrm{WQI}=\sum_{i=1}^{n} W i \times Q i$.

Based on the results, the quality of the water for drinking can be classified to be in five classes (excellent $<50$, good 50-100, poor 100-200, very poor 200-300 and unsuitable $>300$ ) (Vasanthavigar et al. 2010). The groundwater samples in this study have WQI range from 5.63 to 179 ( mean = 64.9), and only one sample has WQI higher than 100, suggesting that these samples are good for drinking when considering about only their major ion concentrations.

\section{Quality Evaluation for Irrigation}

Parameters applied for the suitability evaluation of the groundwater for irrigation include the sodium adsorption ratio (SAR), percentage sodium (\% $\mathrm{Na}$ ), permeability index (PI), residual sodium carbonate (RSC), Kelly's ratio and magnesium ratio (Todd 1995, Michael 2008). In this study, the most popular applied parameters (SAR \& RSC) have been chosen.

SAR expresses the relative activity of sodium ions in the exchange reactions with the soil (Todd 1995). This ratio measures the relative concentration of sodium to the calcium and magnesium. SAR is an important parameter for determining the suitability of groundwater for irrigation. Excess sodium concentration can reduce the soil permeability and soil structure, and irrigation using water with high sodium adsorption ratio may require soil amendments to prevent long-term damage to the soil. SAR is a measure estimated by $\mathrm{Na}^{+} / \mathrm{SQRT}\left(\left(\mathrm{Ca}^{2+}+\mathrm{Mg}^{2+}\right) / 2\right)$ (in meq/L). The calculated values of SAR for the groundwater samples in this study were 2.84-195 $($ mean $=39.4)$. According to the criterion for irrigation (SAR < 10, excellent; 10-18, good; 18-26, doubtful;

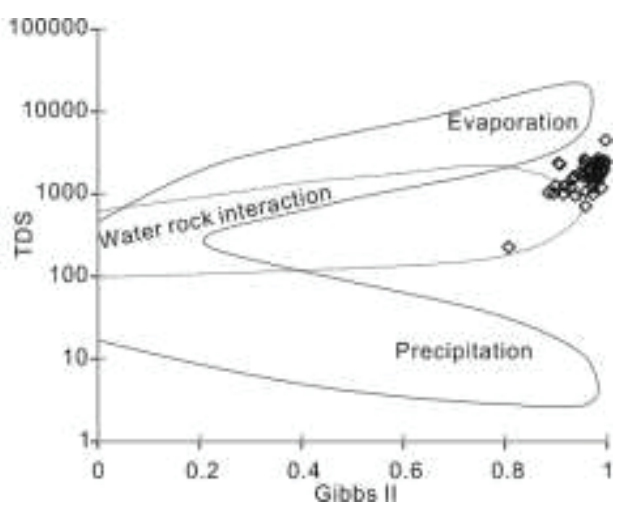

Fig. 3: Gibbs diagram. 
>26, unsuitable) (Richards 1954), 2, 8 and 10 samples were classified to be excellent, good and doubtful, respectively. Such results indicate that these groundwater samples must be treated before the irrigation application.

RSC exists in irrigation water when the carbonate $\left(\mathrm{CO}_{3}\right)$ plus bicarbonate $\left(\mathrm{HCO}_{3}\right)$ content exceeds the calcium $\left(\mathrm{Ca}^{2+}\right)$ plus magnesium $\left(\mathrm{Mg}^{2+}\right)$ content of the water. An excess value of RSC in water leads to an increase in the adsorption of sodium in soil (Michael 2008). The results of this include direct toxicity to crops, excess soil salinity (EC) and associated poor plant performance, and where appreciable clay or silt is present in the soil, loss of soil structure and associated decrease in soil permeability. RSC is a measure employed by calculating $\left(\mathrm{CO}_{3}{ }^{2-}+\mathrm{HCO}_{3}{ }^{-}\right)-\left(\mathrm{Ca}^{2+}+\mathrm{Mg}^{2+}\right)$. RSC values $<$ $1.25 \mathrm{meq} / \mathrm{L}$ indicate good water quality. If the value of RSC is between 1.25 and $2.5 \mathrm{meq} / \mathrm{L}$, the water is slightly suitable while at a value $>2.5$ the water is considered as unsuitable for irrigation. RSC values of the groundwater samples in this study are from -4.54 to $64.6($ mean $=11.0)$. Based on the criterion for irrigation, only 8 samples (16\%) can be used for irrigation directly.

\section{Mechanism Controlling Water Chemistry}

The Gibbs diagram proposed by Gibbs (1970) can be used for understanding the relationship of the chemical components of groundwater from their respective aquifer lithology. Three factors controlling groundwater chemistry can be classified

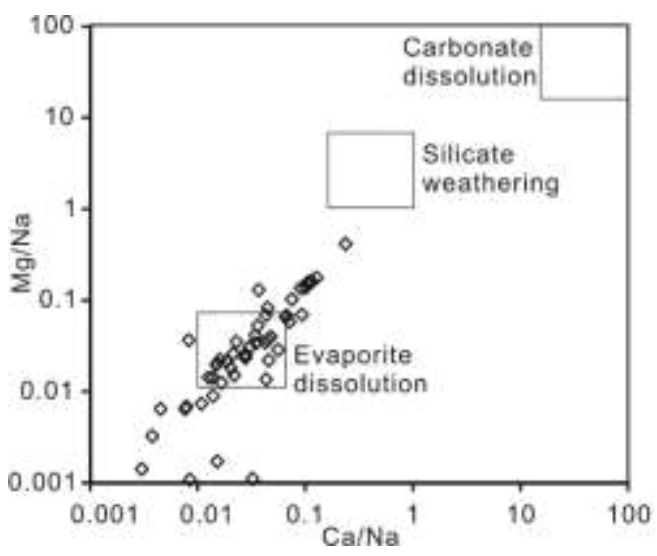

by the diagram: precipitation, evaporation and water-rock interaction dominance. As to the groundwater, these factors are recharge, evaporation (or dissolution of evaporates) and water-rock interaction.

The calculation functions of Gibbs ratios are Gibbs ratio I $=\mathrm{Cl}^{-} /\left(\mathrm{Cl}^{-}+\mathrm{HCO}_{3}{ }^{-}\right)$and Gibbs ratio $\mathrm{II}=\left(\mathrm{Na}^{+}+\mathrm{K}^{+}\right) /\left(\mathrm{Na}^{+}+\mathrm{K}^{+}+-\right.$ $\mathrm{Ca}^{2+}$ ) (in meq/L). In this study, the Gibbs ratio I and II values for the groundwater samples are 0.13-0.94 (mean $=0.60)$ and 0.81-1.00 (mean =0.96), respectively. From the Fig. 3 , it can be seen that most of the samples in this study are plotted into the water-rock interaction and evaporation areas, indicating that the water-rock interaction and the evaporation (or discharge of the groundwater and dissolution of evaporate minerals) in the aquifer systems play an important role for controlling the groundwater chemistry.

Moreover, it can be seen from Fig. 4 that the groundwater samples in this study have $\mathrm{Ca}^{2+} / \mathrm{Na}^{+}$ratios ranging from 0 to 0.24 (mean $=0.04$ ), and $\mathrm{Mg}^{2+} / \mathrm{Na}^{+}$ratios range from 0 to 0.41 (mean $=0.05)$, which suggest that weathering of silicate minerals and dissolution of evaporate minerals are the main types of water-rock interaction in the aquifer system. It is also supported by the correlation between $\mathrm{Ca}^{2+} / \mathrm{Na}^{+}$and $\mathrm{HCO}_{3}{ }^{-} / \mathrm{Na}^{+}$(Fig. 4) that the samples have $\mathrm{HCO}_{3}{ }^{-} / \mathrm{Na}^{+}$range between 0.05 and 1.22 (mean $=0.37$ ). Some other information can also be achieved from the relationships between $\mathrm{Na}^{+}$ and $\mathrm{Cl}^{-}$that all the samples have higher $\mathrm{Na}^{+}$relative to $\mathrm{Cl}^{-}$, which indicates the contribution of $\mathrm{Na}^{+}$from the weather-

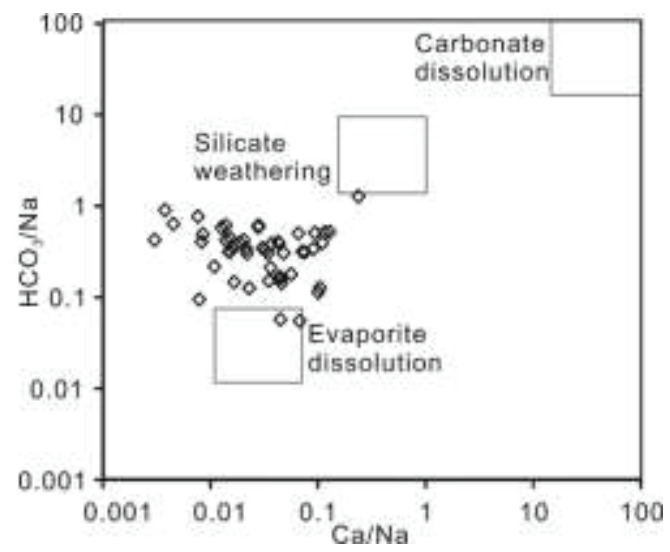

Fig. 4: $\mathrm{Ca} / \mathrm{Na}-\mathrm{Mg} / \mathrm{Na}$ and $\mathrm{Ca} / \mathrm{Na}-\mathrm{HCO}_{3} / \mathrm{Na}$ diagrams.

Table 2: Result of factor analysis.

\begin{tabular}{|lllllllll|}
\hline Species & $\mathrm{Na}^{+}$ & $\mathrm{Ca}^{2+}$ & $\mathrm{Mg}^{2+}$ & $\mathrm{Cl}^{-}$ & $\mathrm{SO}_{4}{ }^{2-}$ & $\mathrm{HCO}_{3}{ }^{-}$ & Eigenvalue & Explained \\
\hline Factor 1 & -0.129 & 0.929 & 0.876 & 0.789 & 0.141 & -0.632 & 2.690 & $44.8 \%$ \\
Factor 2 & 0.945 & -0.098 & -0.059 & 0.326 & 0.721 & 0.540 & 1.823 & $30.4 \%$ \\
\hline
\end{tabular}


ing of silicate minerals except for the dissolution of halite, such consideration is further confirmed by the relationship between $\left(\mathrm{Ca}^{2+}+\mathrm{Mg}^{2+}\right)$ and $\left(\mathrm{HCO}_{3}{ }^{-}+\mathrm{SO}_{4}{ }^{2-}\right)$ that most of the samples (47 in 50) have higher $\left(\mathrm{HCO}_{3}{ }^{-}+\mathrm{SO}_{4}{ }^{2-}\right)$ relative to $\left(\mathrm{Ca}^{2+}+\mathrm{Mg}^{2+}\right)$. During the weathering of silicate minerals, $\mathrm{Na}^{+}$ and $\mathrm{HCO}_{3}{ }^{-}$can be released into the water simultaneously.

\section{Factor Analysis}

As one of the most popular applied mathematical methods, factor analysis has long been used for environmental studies for tracing the source of pollutants (Liu et al. 2003, Almasoud et al. 2015) and also, applied for understanding the source of chemical constitutes in the groundwater (Sun 2018).

In this study, two factors have been extracted based on the factor analysis with an eigenvalue higher than one after varimax rotation (Table 2). As can be seen from the table, the first factor, which accounts for $44.8 \%$ of the total variance explanation, has high positive loadings of $\mathrm{Ca}^{2+}, \mathrm{Mg}^{2+}$ and $\mathrm{Cl}^{-}$, whereas the second factor with $30.4 \%$ of the total variance explanation, has high positive loadings of $\mathrm{Na}^{+}$and $\mathrm{SO}_{4}{ }^{2-}$, and then $\mathrm{HCO}_{3}{ }^{-}$. According to previous studies (Sun $\&$ Gui 2015), these two factors can be explained to be the dissolution of chloride minerals (Factor 1) and the dissolution of sulphate minerals and weathering of silicate minerals (Factor 2). This consideration is consistent with the results obtained by the above analysis (including the Gibbs diagram and the relationships between major ions) that the dissolution of evaporate minerals (including the chloride and sulphate) and the weathering of silicate minerals played an important role for controlling the groundwater chemistry therein.

\section{CONCLUSIONS}

Based on the analysis of the major ion concentrations of the groundwater from the coal-bearing aquifer in four coal mines in the Xinji coalfield, the following conclusions have been made:

(1) The groundwater samples are slightly alkaline with TDS higher than the freshwater $(<1000 \mathrm{mg} / \mathrm{L})$, and most of them are classified to be $\mathrm{Cl}^{-}$and $\mathrm{HCO}_{3}{ }^{-}$types.

(2) The groundwater samples have WQI range from 5.63 to 179 (mean $=64.9)$, only one sample has WQI higher than 100, suggesting that these samples are good for drinking. Comparatively, according to the results of sodium adsorption ratio and residual sodium carbonate, only a few of the samples can meet the requirement of irrigation but must be treated before application.

(3) Gibbs diagram and the relationships between major ions, as well as the factor analysis, implies that water-rock interaction is the main process controlling the groundwater chemistry, including the dissolution of the evaporate minerals (including the chloride and sulphate) and the weathering of silicate minerals.

\section{ACKNOWLEDGEMENTS}

This work was financially supported by the Academic Funding for Top-talents in Disciplines of Universities in Anhui Province (gxbjZD48), the Program of Teacher Applied Competence Development Workstation in Suzhou University (2018XJYY07), and the Foundation of school major leaders (2019XJZY04).

\section{REFERENCES}

Almasoud, F.I., Usman, A.R. and Al-Farraj, A.S. 2015. Heavy metals in the soils of the Arabian Gulf coast affected by industrial activities: Analysis and assessment using enrichment factor and multivariate analysis. Arabian Journal of Geosciences, 8(3): 1691-1703.

Chen, Z., Zhen, L.N., Zhao, J.Z., Qi, J. and Nan, Y. 2005. Isotopes and sustainability of ground water resources. North China Plain, Ground Water, 43(4): 485-493.

Davis, S.N. and Dewiest, R.J.M. 1966. Hydrogeology. Wiley, New York.

Gibbs, J. R. 1970. Mechanisms controlling world water chemistry. Science, 170: 1088-1090.

Gui, H.R. and Chen L.W. 2007. Hydrogeochemistric Evolution and Discrimination of Groundwater in Mining District. Geological Publishing House, Beijing.

Jalali, M. 2005. Major ion chemistry in the Bahar area, Hamadan, western Iran. Environmental Geology, 47: 763-772.

Lin, M.L., Peng, W.H. and Gui, H.R. 2016. Heavy metals in deep groundwater within the coal mining area, northern Anhui Province, China: Concentration, relationship, and source apportionment. Arabian Journal of Geosciences, 9(4): 319.

Liu, C.W., Lin, K.H. and Kuo, Y.M. 2003. Application of factor analysis in the assessment of groundwater quality in a blackfoot disease area in Taiwan. Science of the Total Environment, 313(1): 77-89.

Lvovitch, M.I. 1970. World Water Balance (general report). World Water Balance: Proceedings of the Reading Symposium.

Michael, A.M. 2008. Irrigation Theory and Practice. Vikas Publishing House Pvt. Ltd., New Delhi.

Richards, L.A. 1954. Diagnosis and Improvement of Saline Alkali Soils: Agriculture (Vol. 160). US Department of Agriculture, Washington.

Sun, L.H. 2018. Application of hydrochemistry for inrush water source identification in coal mine: Approach based on statistical analysis. Mining Science, 25: 115-124.

Sun, L.H. and Gui, H.R. 2013. Groundwater from deep limestone aquifer in Linhuan coalfield, northern Anhui Province, China: Quality and controlling factor analysis. International Journal of Applied Environmental Sciences, 8(2): 167-176.

Sun, L.H. and Gui H.R. 2015. Hydro-chemical evolution of groundwater and mixing between aquifers: A statistical approach based on major ions. Applied Water Science, 5(1): 97-104.

Todd D. K. 1995. Groundwater Hydrology. John Wiley and Sons Publications, 3rd Ed, New York.

Toth, J. 1999. Ground-water as a geologic agent: An overview of the cause, processes and manifestations. Hydrogeology Journal, 7: 1-14.

Varol, S. and Davraz, A. 2015. Evaluation of the groundwater quality with WQI (Water Quality Index) and multivariate analysis: a case study of the Tefenni plain (Burdur/Turkey). Environmental Earth Sciences, 73(4): 1725-1744. 
Vasanthavigar, M., Srinivasamoorthy, K., Vijayaragavan, K., Rajivganthi, R., Chidambaram, S., Anandhan, P., Manivannan, R. and Vasudevan, S. 2010. Application of water quality for groundwater quality assessment: Thirumanimuttar Sub basin, Tamil Nadu, India. Environmental Monitoring and Assessment, 171(1-4): 595-609.
WHO 2008. Guidelines for Drinking Water Quality. World Health Organization, Geneva.

Zhang, Z.H., Shen, Z.L., Xue, Y.Q., Ren, F.H., Shi, D.H., Yin, Z.Z. and Sun, X.H. 2000. Evolution of Groundwater Environment in North China Plain. Geological Publishing House, Beijing. 